\title{
EL PODER DE LA PALABRA
}

UN ENCUENTRO DE AFECTO Y SOLIDARIDAD CON JAVIER OSUNA

\section{THE POWER OF THE WORD}

AN AFFECTIONATE AND SOLIDARY REUNION WITH JAVIER OSUNA

\section{O PODER DA PALAVRA}

\section{UM ENCONTRO DE AFETO E SOLIDARIEDADE COM JAVIER OSUNA}

\section{Páginas Germán Muñoz}

116-120 gmunozg2000@yahoo.es

Director de la Maestría en Comunicación y Educación en la Cultura, Corporación Universitaria Minuto de Dios - UNIMINUTO 
La siguiente composición es un homenaje al valor de Javier Osuna, cuyo trabajo dignifica, en tiempos superficiales, el oficio del periodista.

Palabras clave

Javier Osuna, palabra, Colombia, víctimas 


\section{Abstract}

The following text is a tribute to Javier Osuna, whose labor dignifies, in times of light appreciation of the craft, the journalism commitment.

\section{Key words}

Javier Osuna, Colombia, Victims

\section{Resumo}

A seguinte composição é uma homenagem ao valor de Javier Osuna, cujo trabalho dignifica, em tempos superficiais, o oficio do jornalista.

\section{Palavras-chave}

Javier Osuna, palavra, Colômbia, vítimas 
Celebramos hoy, en medio de circunstancias difíciles, a Javier Osuna, maestro de la palabra. Y con razón, porque, en el momento histórico que vivimos en Colombia, la recuperación de la historia, el poder de la palabra y del relato, requieren voces que la narren con valor.

La palabra y el lenguaje nos han permitido estar, ser y permanecer de múltiples formas. Ahora nos permiten que Colombia sea un ágora de innumerables voces. Hoy la palabra atraviesa toda la escena social y del conflicto, pues, la palabra cuenta, aunque está sometida a muchos usos y abusos.

Está la palabra de las víctimas, la palabra de los perpetradores y la palabra de los periodistas y académicos. Esta última es la que ha enaltecido en su práctica Javier.

Sin duda, en nuestro contexto político la palabra que adquiere mayor valor, y que es uno de los hilos con los cuales hemos comenzado a tejer la memoria es la palabra de las víctimas. Las víctimas han empezado a hablar, no solamente hoy, sino desde hace décadas. Han logrado que su voz se escuche y que sea tenida en cuenta. Cada vez que pueden han surgido a través de la palabra y sus relatos. Y gracias a la palabra buscan cambiarle el sentido a su condición de víctimas.

La palabra les ha permitido empoderarse políticamente y convertirse en protagonistas y sujetos de derechos. La palabra ha potenciado su capacidad de enunciación, la fuerza de su reclamo y de sus propuestas de transformación y superación. Porque las víctimas han llegado a ser, en la Colombia de hoy, narradoras de lo que les pasó, de los hechos atroces, testigos contra los perpetradores, de quiénes les victimizaron y de las huellas que les dejó la barbarie. Su palabra circula. Y algo mueve su palabra y sus voces se oyen y retumban.

Con la palabra de las víctimas tejemos memoria, tejemos país y tejemos futuro. Al mismo tiempo se ha empezado a escuchar otra palabra, especialmente en los escenarios judiciales, públicos y políticos de nuestro país. Una palabra que ha revelado el horror, que ha mostrado la capacidad del ser humano de hacer daño, y que ha hecho evidente la razón de los reclamos de las víctimas, las causas profundas de aquello que conmueve a la sociedad entera.

Es la palabra del perpetrador, la que ha servido en ocasiones para aceptar responsabilidad y para confesar, pero también, muchas veces para legitimar y ocultar las tropelías.Su palabra ha puesto al descubierto el rostro, el cuerpo y el dolor de las víctimas. Sin embargo, su palabra expresa muchas verdades mutiladas y justificaciones oprobiosas. Porque habla desde el lugar del poder absoluto, disfrazando muchas veces las identidades de los autores intelectuales e instigadores.

La palabra de los perpetradores ha sido pública y ha tenido gran resonancia mediática, incluso en el recinto del Congreso. Se les ha dado más espacio que a las víctimas. ¿Con qué intención? ¿Con la intención de confesar y resarcir, o con la pretensión de encubrir y legitimar o minimizar las atrocidades cometidas?

Los perpetradores han trastocado la función de la palabra que es comunicar, la han usado frecuentemente para ocultar, tergiversar y confundir.

Una tarea fundamental consiste hoy en develar la verdad de su palabra, es una tarea de la memoria. Los hilos con los que tejemos la memoria también deben elegir cuáles de las palabras de los perpetradores narrarán nuestra guerra. Y elegir aquellos hilos de la confesión que claman por la no repetición.

Finalmente, está la palabra de los narradores, de quienes tiene oídos para escuchar y testimoniar desde el lugar del dolor, desde la memoria de quienes han estado en frente de la muerte y han sobrevivido. Se trata de la palabra de quienes construyen relato, historia y conocimiento. Me refiero a la 
palabra de algunos periodistas, pero también a la palabra de los académicos.

No se trata de entender la palabra como fuente. Porque la fuente está en la escena de los hechos, en la vida de los protagonistas. La palabra de los testigos, de los periodistas, es la caja de resonancia pública de lo acontecido.

Los periodistas críticos y comprometidos son los mediadores entre protagonistas y sociedad, entre lo acontecido y lo relatado. La sociedad, a través de ellos, puede acceder al lugar de los hechos, ver lo acontecido y los protagonistas; puede entender o no las escenas, puede recoger con su conocimiento hechos, emociones, sensaciones y tramas narrativas.

Un buen relato periodístico, traducido en crónicas, convierte a los testigos en informantes, más aún, en intérpretes de los contextos, y hace que sus voces sean fuente de una verdad necesaria para el resarcimiento de las víctimas. El testigo y el periodista, aunque no son depositarios de la verdad, tienen una inmensa responsabilidad frente a ella. Porque contar y descifrar la palabra de los otros y las otras, de víctimas y/o perpetradores, abre la puerta a la justicia al poner en la esfera pública historias que de otra manera quedarían en la ignorancia o el olvido. La palabra del periodista se despliega en los escenarios de las luchas políticas, en los escenarios de la memo- ria. Las palabras del periodista y la del académicoson los hilos con los cuales tejemos memoria.

La narración periodística, así como la de los académicos no es pasiva o neutra. Produce conocimiento e interpretación de múltiples realidades, y también trasluce preferencias. Todas estas palabras y voces que he puesto de relieve en estas reflexiones, enfrentan hoy, en esta inmensa ágora que es Colombia, en el espacio abierto de la negociación, un reto: sobrevivir a la guerra y convertir el silencio en grito contra la violencia. Esta es la misión del momento: ser palabra para nombrar la devastación que ha dejado la guerra. Ser palabra de sobrevivientes en resistencia a la guerra, ser palabra para la paz.

En Colombia, la potencia de la palabra que habla no ha sido predominante, lo ha sido la palabra silenciada a lo largo de décadas. Aquí, de alguna manera, nos ensordecen las voces de los silencios inducidos por las violencias cruzadas del país.Una voz plena de coraje que clama por la verdad, a favor de las víctimas, ha sido la voz de Javier Osuna. El poder de su palabra recibe hoy nuestro reconocimiento. La palabra del periodista y del maestro vigoroso y lúcido que no calla ante el amedrentamiento de los poderes armados.

¡Fuerza, Javier! 